\title{
Empirical Study on the Design and Implementation of Online Courses at the Training Center During the COVID-19
}

\author{
Chenxin Wang ${ }^{1, *}, Z^{\prime}$ 'an Jiang ${ }^{1}$ and Ye Zhu ${ }^{1}$ \\ ${ }^{1}$ Shanghai International Studies University, Institute of Linguistics, China, Shanghai, 201620 \\ *Chenxin Wang. E-mail: wangcx@shisu.edu.cn
}

\begin{abstract}
Off-campus training plays an important role in China's education system. During the COVID-19 in 2020, the off-campus training institutions respond to the call of the Ministry of Education of China by replacing the offline course with online education. However, this kind of teaching mode forced by the epidemic situation inevitably has problems. In view of this, this paper takes an off-school training institution in Shanghai as the research object, carries out design-based research as methodology and presents the current situation of online curriculum design and present situation of off-campus training institutions during the epidemic through participatory observation, questionnaire survey and interview and other data collection methods. Reflections and suggestions around the research are made so as to provide reference for the field based on the experience. Keywords: off-campus training, online courses, teaching design, COVID-19
\end{abstract}

\section{INTRODUCTION}

During the COVID-19, the Ministry of Education asked for the spring semester in 2020 to be postponed to ensure students' safety. All training institutions should cancel all kinds of offline courses according to the requirements, and use the network platform to stop the class but not stop learning [1]. However, the training center received limited supports from the government and society. Meanwhile, the suspension of offline courses has also caused great losses to the off-campus training industry. The revenue of most training institutions in the first half of 2020 decreased by more than $50 \%$ compared with the same period of last year [2]. As one of the participants in the field of education, offcampus training institutions have to try to design and implement online courses or transfer offline courses to online courses in order to avoid economic losses.

\section{TERMINOLOGY}

Off-school training is an important part of after-school service. Private off-school training institutions and private family trusteeship jointly constitute the two main bodies of after-school service institutions [3]. In 2018, the general office of the Ministry of Education issued "Notice on rectification of some working mechanisms for special governance on off-campus training institutions", which defines "off-campus online training" as "subject online training activities for primary and secondary school students implemented through the Internet. [4]"

\section{LITERATURE REVIEW}

In recent years, online curriculum design has always been a frontier issue in the field of education. The related researches focus on different teaching objects. It can be divided into online course design in universities (Shi Yinlian, Zhang Wei, Liu Meifang, 2020 [5]; Liu Li, Ma Chizhu, 2020 [6]; Duan Jinju, Zheng Ling; 2019 [7]), online curriculum design for primary and secondary schools (Meng Jiuer, 2020 [8]; Mao Luo, 2020 [9]), etc. Few related types of research are focusing on the students of off-campus online training institutions. There is a huge contrast between the market scale of off-campus online training and the number of related academic achievements. In the first quarter of 2020 , the online education market scale is 68.06 billion yuan [10], which is expected to reach 543.35 billion yuan in 2022 [11]. The relevant departments in China have been aware of the new changes in the field of off-campus education. The Ministry of Education and other six departments jointly issued the "Opinions on standardizing off-campus online training”, proposing clear requirements and specific standards for the construction of this field. Because of this, the author thinks that offcampus online training should also get the continuous attention of academia. 


\section{RESEARCH DESIGN}

\subsection{Research object}

This paper selects a private off-campus training center in Shanghai as the research object. Founded in 1998, the training center is one of the first training institutions registered by the Ministry of Education, with more than 30 years of experience in formal off-line education. The students are all primary and secondary school students in Shanghai, aged between 6 and 15 .

\subsection{Research questions}

Based on the literature review and previous participatory observation, this study aims to answer the following research questions:

1. How do off-campus training institutions carry out online courses during the prevention and control period of COVID-19?

2. How is the effect of online courses during the prevention and control period of COVID-19?

3. How should off-campus training institutions improve the effect of their online courses?

\subsection{Research methods}

The author was invited to participate throughout the online course design and implementation of the training institution. All the reference policy documents and meeting records during the online course construction of the training center were collected through participatory observation.

The research is based on the Successive Approximation Model (SAM) model [12] proposed by Allen (2003). This design of the study was carried out through three links: course preparation, iterative design and iterative development. In addition, after the implementation of each online course, the training center invited students and their parents to complete the questionnaire survey on course evaluation designed by the center voluntarily. After obtaining the permission of the training center, the author collates and analyzes the questionnaire data to find out the problems existing in online teaching.

\section{RESEARCH PROCESS}

As online course design often involves multiple groups, how to ensure efficient design should be one of the main considerations of designers [13]. The training center invited four administrators, three senior teachers and one technical personnel to form an online course design team. Through several video conferences, the course design elements including organizational conditions, learners, learning situations, learning resources, learning activities, support and management [13] were determined, and training was carried out on the technical operation ability of software and hardware of the teachers. In the iterative design stage, the teachers completed the design task of repeating design, example and evaluation [13].

After the completion of the online course design, the training center carried out two rounds of online courses. The first round of online courses are news gathering and editing, English writing and sketching. The students are all grade three, four and five. Parents accompany them during the course. The first round of online courses adopts the teaching mode of recording and broadcasting + Wechat Q \& A (Fig. 1)

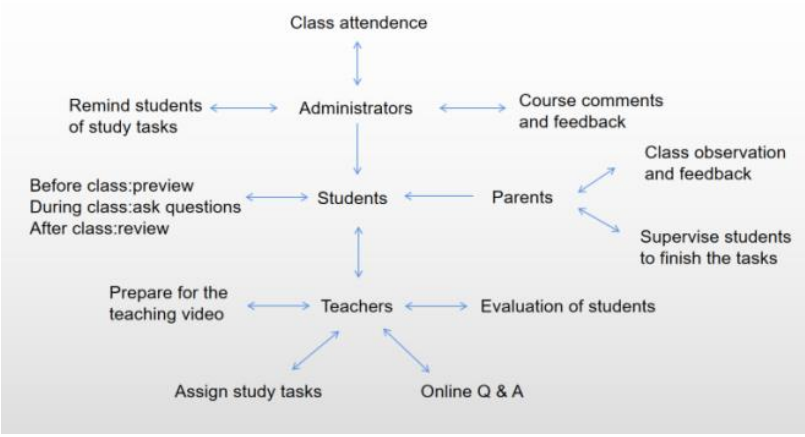

Figure 1. Teaching mode of recording and broadcasting + Wechat Q \& A

Based on the findings of the feedback from the questionnaire of students and parents, the teaching mode of live broadcast and cloud platform was adopted in the second round of online courses (Fig. 2). Compared with the first round, two design adjustments were made: 1) students of news gathering and editing and English writing course were divided into junior class and senior class according to grade 3 , grade 4 and grade $5 ; 2$ ) live broadcasting was carried out, and the video of the course was still distributed before class for students to preview.

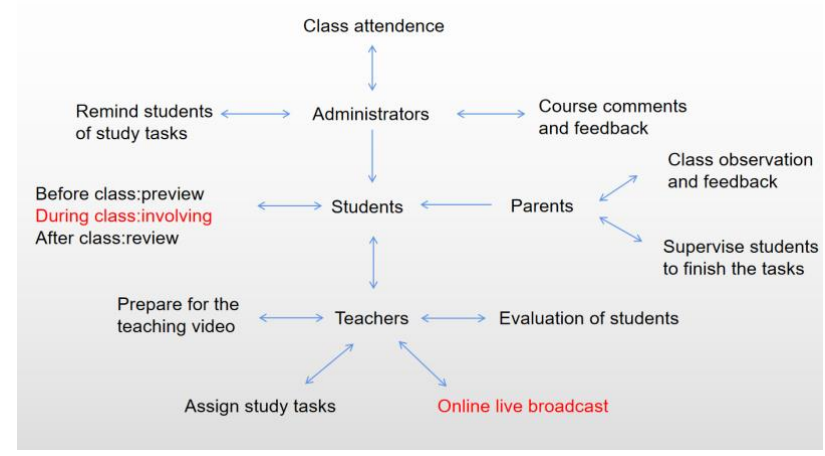

Figure 2. Teaching mode of live broadcast and cloud platform

\section{RESULTS}

It is found that there is a phenomenon of multi-agent participation in the design and implementation of the 
online course. Based on different background and needs, the factors are also different. At the same time, iterative design is helpful to improve the quality of off-campus online courses.

(1) Multi-agent participation in online course design It is found that in the whole process of course design and implementation, administrators, teachers, technicians, students and parents' representatives are deeply involved, and play different main roles. (Fig. 2). Each subject keeps a close cooperative relationship, and provides opinions and suggestions on course design and development from different perspectives.

(2) Multiple factors consideration of different participants It is found that different participants pay different attention to online course design (Table 1). In the online course design, the training center recommends the use of a cloud platform, and suggests the online courses adopting the teaching mode of recording and broadcasting + Wechat Q $\&$ A. The reasons include three aspects: 1) expenditure the platform has signed a cooperation agreement with the training center, which provides free technical support. 2)
Technical conditions: the platform does not have the function of live broadcasting. 3) risk management: live broadcasting is uncontrollable and has security risks. However, all three teachers objected, believing that there are more interactive opportunities in live broadcasting and the teaching effect may be better. The training center decided to adopt the teaching mode of video recording and broadcasting + Wechat Q \& A in the first round of online courses, which reflected the priority of organizational factors.

In the interview, the administrators also affirmed the class atmosphere of live broadcasting but said that the first attempt at online broadcasting should be based on information security. Recording and broadcasting video can be reviewed in advance, which can ensure that the video content meets the relevant requirements. At the end of the first round of courses, the training center expressed its full trust in teachers and accepted the demands from students and parents for live broadcasting. The key point now shifts to the teaching effect.

Table 1 Participants and their focus

\begin{tabular}{|l|l|l|}
\hline Participants & Factor & Focus \\
\hline Training center & $\begin{array}{l}\text { Organizational } \\
\text { condition }\end{array}$ & Policy, technical condition, expenditure and risk management \\
\cline { 2 - 3 } & $\begin{array}{l}\text { Support and } \\
\text { management }\end{array}$ & $\begin{array}{l}\text { The time of course, teaching management method, technical support needed by } \\
\text { teachers and students. }\end{array}$ \\
\cline { 2 - 3 } & Teaching effect & Satisfaction and renewal rate of parents and students for online course \\
\hline \multirow{4}{*}{ Teacher } & Learner & Students' learning style, motivation, level \\
\cline { 2 - 3 } & Teaching situation & Technical conditions owned by students \\
\cline { 2 - 3 } & Teaching activities & The effectiveness and acceptability of teaching activities \\
\cline { 2 - 3 } & Teaching resources & The interest and pertinence of teaching resources \\
\cline { 2 - 3 } & Teaching effect & Teaching goal,parents' expectation \\
\hline \multirow{3}{*}{$\begin{array}{l}\text { Students and } \\
\text { parents }\end{array}$} & Teaching effect & Students' progress and expectation \\
\hline
\end{tabular}

(3) Iterative design improves the quality of online courses

The iterative design and development mode of off-campus online courses helps to improve the quality of online courses. The satisfaction of the first round of teaching mode was $67 \%$, and $70 \%$ of the students and their parents were willing to pay for the follow-up online courses. In the interview, the parents of the students also pointed out two main problems in the first round of the course: 1) the language level of the students in the same class is quite different, and the course lacks pertinence; 2) the interaction of Wechat Q \& A is not good, which affects students' learning mood.

The satisfaction rate of the second round of teaching mode was $84.21 \%, 78.94 \%$ of the students and their parents were willing to pay for the follow-up courses, and the satisfaction and renewal rate was improved compared with the first round. In the interview, administrators, teachers and students' parents also affirmed that live broadcasting is more interactive than video broadcasting + Wechat $\mathrm{Q} \& \mathrm{~A}$, and the class atmosphere is better. At the same time, it also points out two main problems existing in the second round of courses: 1) the course content lacks creativity and features; 2) online teaching activities mainly focus on question and answer, and the form is not rich. Such problems will be further improved in the subsequent iterative design.

\section{DISCUSSION}

In this online course design and implementation, the author, as a participant, also found several deficiencies, which are summarized as follows:

First of all, in order to ensure the controllability of the teaching content, the decision-making layer rejected the suggestion of using the live broadcasting mode proposed by teachers in the iterative design stage, which reflects its contempt for the teaching rules. The teaching content is the key point of teaching design, and the quality of teaching content is reflected in many aspects, not only the health and safety of the content, but also the pertinence, interest and other elements. Compared with administrators, teachers should be more professional and have a voice in the choice of teaching content. In view of this problem, It is suggested that the training center should strictly control the selection of teachers, and endow teachers with more 
autonomy in teaching design to ensure that both teaching safety and teaching effect are taken into account.

In addition, due to the lack of off-campus online teaching experience, only based on the relevant online teaching theory learning, cannot fully meet the learning needs of all students. The course content lacks innovation, teaching activities are single. In view of this problem, the author suggests that the training center invites excellent online teachers to conduct demonstration teaching, organize relevant personnel to carry out teaching discussion, and teachers should also timely carry out teaching reflection to improve the level of online teaching.

At the same time, in the context of the national and local departments have issued relevant regulations on offcampus online training, offline training institutions are still content with the status before the outbreak of the epidemic, and lack of online course construction plan and crisis response means, which is one of the reasons for the heavy losses in the epidemic. This exposed the offline training institutions' innovation consciousness in the teaching mode is insufficient. The use of modern educational technology methods is not enough. In view of this problem, the author suggests that the relevant departments should gradually carry out the demonstration and guidance of online transformation of offline training institutions on the basis of further refining policy norms and industry standards, so as to provide more reference and basis for relevant institutions.

\section{CONCLUSION}

This study shows that under the guidance of relevant policies and theories, the offline training center can independently design and develop online courses to meet the needs of most students and parents through the multisubject participation mode. In the specific operation, the main body based on different perspectives considers multiple factors. The follow-up research will focus on how to improve the teaching effect and other issues, providing ideas and references for relevant scholars in this field.

\section{REFERENCES}

[1] Ministry of Education. "suspend the course but not stop learning in the use of the online platform". http://www.moe.gov.cn/jyb_xwfb/gzdt_gzdt/s5987/202 001/t20200129_416993.html,2020.(In Chinese).

[2] Iimedia Consulting. https://www.iimedia.cn/c1061/70566.html,2020.(In Chinese).

[3] Wu Kaijun, Meng Weiqing. System design of after class trusteeship of junior students from the perspective of governance[J]. Education Studies,2015,36(6): pp. 5563(In Chinese).
[4] Ministry of Education."The notice on rectification of some working mechanisms for special governance on off-campus training institutions". http://www.gov.cn/xinwen/2018 11/26/content_5343383.htm,2018 (In Chinese).

[5] Shi Yinlian, Zhang Wei, Liu Meifang. An example of microscope online course design based on interest learning [J]. Journal of Southwest Normal University (Nature Science),2020,45(04): pp. 138-142. (In Chinese).

[6] Liu Li, Ma Chizhu. Online emergency teaching design with research-based learning as the core during epidemic prevention and control -- Taking "TV director" online course as an example [J]. Modern education technology,2020,30(06):pp.120-126. (In Chinese).

[7] Duan Jinju, Zheng Ling. Curriculum design based on knowledge community and inquiry and shared knowledge: Empirical Research and application analysis of associated learning [J]. Journal of distance education,2019,37(01): pp.72-84. (In Chinese).

[8] Meng Jiuer. "suspend the course but not stop learning": promoting the re-upgrading of online education in primary and secondary schools $[\mathrm{J}]$. School management, 2020 (03): pp. 31-33(In Chinese).

[9] Mao Bo. Curriculum design based on social reality problems: Taking the online course of "talking about anti-epidemic" in 2020 as an example [J]. Basic education curriculum, 2020 (09): pp.14-19(In Chinese).

[10] Iresearch. 2020 Q1 online education market scale 68.06 billion, a year-on-year increase of $3.9 \%$. http://report.iresearch.cn/content/2020/04/322437.shtml, 2020.(In Chinese).

[11] Analysis on the market development trend of the off-campus training industry in 2020.

https://www.reportrc.com/article/20200208/3957.html,2 020.(In Chinese).

[12] Michael Allen. SAM curriculum design and development [M]. Translated by Ren Mai learning technology research and development center. Beijing: Electronic Industry Press, 2015:p.69(In Chinese).

[13] Jin Hui. Theory and practice of online learning: the perspective of curriculum design [M]. Beijing: Tsinghua University Press, 2018:pp. 65-68(In Chinese). 